\title{
Which policies matter? \\ Explaining naturalisation rates using disaggregated policy data
}

\author{
Jeremias Stadlmair ${ }^{1, *}$ \\ 1 Department of Political Science, University of Vienna, Austria \\ * E-Mail: jeremias.stadlmair@univie.ac.at
}

\begin{abstract}
Despite similar experiences of immigration, the proportion of immigrants taking up the citizenship of their country of residence varies substantially in Western European countries. While previous research concluded that citizenship policies in general are relevant for explaining these differences, this paper provides a fine-grained analysis of which policy dimensions bear greater or lesser importance for naturalisation outcomes. Drawing on citizenship policy data from nine EU countries for the period 1995 to 2014 and using time-series cross-section regression models, the study identifies economic requirements, ius soli, and dual citizenship provisions as main drivers for differences in naturalisation rates.
\end{abstract}

\section{Keywords}

Citizenship, immigration, naturalisation, policy analysis, boundary making

\section{Welche Kriterien machen den Unterschied? Einbürgerungsraten und Einbürgerungsbestimmungen im europäischen Vergleich}

\section{Zusammenfassung}

Trotz ähnlicher Migrationsbewegungen unterscheiden sich westeuropäische Staaten im Anteil jener MigrantInnen, die die Staatsbürgerschaft ihres Aufenthaltslandes annehmen. Während bestehende Forschung damit schließt, dass heterogene Staatsbürgerschaftspolitiken einen zentralen Erklärungsfaktor für Divergenz darstellen, bietet dieser Beitrag eine detaillierte Analyse, welche Aspekte von Einbürgerungspolitiken größeren und welche geringeren Einfluss auf Einbürgerungsraten aufweisen. Basierend auf einer Regressionsanalyse von Einbürgerungsraten und -policies in neun EU-Staaten über den Zeitraum von 1995 bis 20I4, zeigt der Beitrag, dass vor allem ökonomische Einbürgerungsvoraussetzungen, Ius Soli und Bestimmungen zu Doppelstaatsbürgerschaft Ursachen für diese Varianz darstellen.

\section{Schlüsselwörter}

Staatsbürgerschaft, Einbürgerung, Immigration, Policyanalyse, Grenzziehungsprozesse

\section{Acknowledgements}

I would like to thank Sieglinde Rosenberger for her supervision and support in the overall PhD project, of which this paper is part, and for her comments strengthening an earlier draft of the paper. Thanks also go to Didier Ruedin, Markus Wagner, and the anonymous reviewer of the OEZP for their comments and suggestions.

The author has declared that no competing interests exist. 


\section{Introduction}

As international migration blurs the congruence of citizens with residents of a(ny) state, the politics of naturalisation - in the sense of acquiring citizenship other than by birth - attract considerable public and scholarly attention. Questions of who should be able to become a citizen and who should not are politically contested and citizenship policies differ widely across European countries (Goodman 20I4; Howard 2009; Koopmans et al. 2005). This variation includes different residence requirements, naturalisation conditions, procedural structures and positions on dual citizenship (Huddleston et al. 20II; Koopmans et al. 20I2). Although some aspects may have a mostly symbolic function - displaying the characteristics of an ideal citizen (van Houdt et al. 2OII) - the core function of citizenship policies is to regulate outcomes, i.e. the acquisition or loss of citizenship. These outcomes are important for an individual's opportunities in society (OECD 2OII) as well as for democratic societies as a whole, by defining the legitimising basis of democratic government (Bauböck 2010). Therefore, the outcomes of citizenship policies have attracted substantial academic interest in recent decades (Brubaker I992; Hagedorn 200I; Janoski 20IO; Reichel 20II, 2012; Vink et al. 2013).

This paper examines how citizenship policies relate to naturalisation rates, investigating which naturalisation policy dimensions can explain the variation in naturalisation rates across nine western European countries (Austria, Belgium, Denmark, Finland, Germany, Ireland, Netherlands, Sweden and the United Kingdom) for the period 1995 to 20I4. It assesses whether (a) ius soli, (b) residence requirements, (c) naturalisation conditions, (d) procedural security, and (e) dual citizenship provisions can account for different levels of naturalisation rates. Within the dimension of naturalisation conditions, specific attention is given to civic integration requirements (Goodman 20I4), economic resource requirements (Stadlmair 20I4), and naturalisation fees as potential sources of variation.

As comparable data on immigration and citizenship acquisitions remains relatively scarce, most research on consequences of citizenship policies draws on case studies of single or few countries (Brubaker 1992; Hagedorn 200I; Koopmans et al. 2005), which by design can only provide indicative findings. With increasing quality of comparable data provided by EUROSTAT and the OECD, some recent studies use quantitative macro-comparisons on the effect of citizenship policies on naturalisation outcomes (Janoski 20IO; Reichel 20II, 20I2; Vink et al. 20I3). As these approaches build on comprehensive citizenship policy indices, they primarily show that policies matter overall, but do not provide insights on which dimensions of naturalisation policies are more (and which are less) relevant for naturalisation outcomes: Does the length of residence requirements encourage or prevent immigrants from naturalising, do higher naturalisation fees lead to fewer naturalisations? Questions like these go beyond a general finding that policies matter, but are of crucial importance given the increasing complexity and number of conditions for naturalisation.

The next section reviews recent literature on factors shaping naturalisation, with a distinct focus on policy-level factors, leading to hypotheses guiding the analysis, which are operationalised in section 3; in section 4 , the findings of the multivariate regression analysis are presented; section 5 discusses the main findings, followed by a concluding summary and potential perspectives for future research in section 6 .

\section{State of the art}

Apart from individual-level factors and factors related to the country of origin, the institutional context of the destination country shapes an individual's propensity to naturalise (Peters et al. 2016; Vink et al. 2013; Yang 1994). While studies focusing on individual-level determinants of citizenship acquisition rely on survey or register data (Bevelander/DeVoretz 2008; Reichel/Perchinig 2015; Vink et al. 2013), an analysis of macro-level determinants of naturalisation outcomes requires multi-level models (Vink et al. 20I3) or aggregate data (Janoski 20IO; Reichel 2OII). For an analysis of (macro-level) destination-country determinants of naturalisation, aggregate data constitute a straightforward approach, as they allow including a larger number of countries and may also cover a longer period of time. This approach comes at the expense of not allowing to draw conclusions on individual-level naturalisation determinants. Studies investigating cross-national differences in immigrant naturalisation associate four main destination country factors influencing naturalisation rates: immigrant inflows, economic development, government composition and citizenship policy configurations (Janoski 20IO; Reichel 2OII);

First, naturalisations are a consequence of immigration, where higher immigrant inflows could be assumed to lead to higher naturalisation rates. Janoski (20IO) shows empirically that this effect is not as straightforward as one might think, as the transition from immigration to acquiring the citizenship of the country of residence is mediated by economic development, citizenship policies and the wider political climate. Factors stemming from the country of origin may have an additional macro-level impact. In particular, EU citizens are less likely to naturalise in another EU country, as the benefits of naturalisation are smaller for them than for non-EU citizens (Dronkers/ 
Vink 20I2). Thus immigrant inflows from EU countries may have different consequences than inflows of third countries. Overall, immigration can be considered as a sine-qua-non for naturalisation, but this effect may not be a direct one.

Second, naturalisation rates tend to be higher in countries with greater economic development and tend to increase with economic development. In particular, the temporal and cross-national variation in the Gross Domestic Product (GDP) per capita corresponds to levels and changes in naturalisation rates (Janoski 2010, 239-240).

Third, the strength of different political parties relates to immigrant naturalisation, with left-wing parties accounting for higher naturalisation rates: As agents of de-ethnicisation (Joppke 2003), left-wing parties contribute to immigrant naturalisation on a discursive level, by enabling naturalisation in terms of policy and via inclusive policy implementation (Janoski 20IO). Importantly, such an effect is not confined to policy development alone, as Janoski finds an independent effect of left politics on naturalisation rates. Thus, left-wing party strength needs to be included as a separate factor in macro-level models on immigrant nationalisation.

\section{Citizenship policy configurations and their impact on naturalisation outcomes}

Apart from immigration, economic development and relative strength of parties of the left, naturalisation rates are influenced by policy configurations: More inclusive policies correspond to higher naturalisation rates, more exclusive policies to lower rates (Dronkers/ Vink 20I2; Janoski 20IO; Reichel 20II, 2012). ${ }^{\mathrm{H}}$ However, taking other factors in comprehensive models on immigrant naturalisation into account, the effect of policies is often very weak and calls for further attention: As such, studies find that policies matter more for immigrants from less developed countries than for those from more developed ones (Peters et al. 2016; Vink et al. 2013). Furthermore, not all aspects of citizenship policies seem to be equally important. This, however, calls for disaggregating policy data into separate dimensions of citizenship policies:

Using MIPEX data, but no - arguably necessary control variables, Reichel (2OII) compares naturalisation rates and the MIPEX dimensions (Eligibility, Conditions for Acquisition, Security of Status, and Dual Nationality) in 29 Eu-

I Which criteria of a policy configuration should be considered inclusive or exclusive is subject to various operationalisations and normative discussions. The probably most prominent approach is taken by the MIPEX project, for which inclusiveness is defined as citizenship policies corresponding to recommendations of the Council of Europe (Huddleston et al. 20II). Currently the index includes 3I indicators on citizenship policy, representing a one-dimensional continuum of exclusion - inclusion. ropean countries in the years 2007/2008 and concludes that dual citizenship regulations matter particularly for naturalisation. As acknowledged by Reichel, this model does not include control variables: Most importantly, independently from policy change, immigrant inflows, which cannot be expected to be constant or homogeneous across countries, may lead to changes in naturalisation rates. Other factors, in particular economic development and party politics, may have a mediating effect on the correlation between policies and naturalisation rates (Janoski 20IO). Lastly, not only differences across countries may be of interest here, but also changes within countries may be used to make inferences on the impact of citizenship policies on naturalisation rates.

\section{Hypotheses}

As the MIPEX index does not only focus on naturalisation but also on citizenship acquisition based on birthplace (ius soli), this aspect should be kept separate in any model on immigrant naturalisation: If citizenship is also available via ius soli, there should be fewer naturalisations than in cases where citizenship at birth can only be acquired via ius sanguinis (Janoski 2013; Reichel 2012). On the other hand, if ius soli is not available, naturalisation rates may also be deflated, as the number of foreign residents (the denominator of naturalisation rates) will increase not only due to inflows, but also due to births of foreign citizens on a country's soil (Vink 2010). Anyway, ius soli provisions may play a role for assessing naturalisation rates independently from naturalisation policies per se, leading to a first hypothesis:

(A) If citizenship is available for second and third generation immigrants via ius soli, naturalisation rates are lower, because these persons do not need to undergo a naturalisation procedure in order to acquire the citizenship of their country of residence.

Residence requirements regulate for how long a foreign person must have resided in a country in order to naturalise and which legal formats qualify as residence. As Floris et al. (2016, 37I) find that the propensity to naturalise decreases with longer individual residence, naturalisation rates as macro-level measure may not only be delayed, but also lower when residence requirements are long or selective in terms of their legal format. Reichel (20II) does not find such an effect, but as the measurement of residence requirements in the original MIPEX structure underlying his analysis also includes ius soli, this does not refute the following hypothesis:

(B) More inclusive and shorter residence requirements lead to higher naturalisation rates, because immi- 
grants are more likely to naturalise in earlier stages of their residence.

Once a foreign citizen qualifies for naturalisation in terms of residence, there are several requirements to be met, which vary across countries and over time. Summarising requirements on language and civic skills, economic resources, good conduct, good character and the payment of a naturalisation fee to an index, inclusive conditions - meaning no or easy-to-meet requirements - should correspond to higher naturalisation rates (Reichel 20II). The underlying mechanism here is that the costs for meeting the requirements - literally as fees or in terms of time and effort - decrease with fewer or easier requirements and consequently the number of persons fulfilling these requirements may be higher. Looking at specific requirements, especially naturalisation fees and economic resource requirements are highlighted in the literature as potential barriers to naturalisation (de Groot 1989, 263-270; Reichel 20II, 2-3). Civic integration requirements - such as language and cultural knowledge courses and exams - may be understood primarily as symbolic politics (Mourão Permoser 2012), but, at least in Denmark, citizenship testing can be attributed to changes in naturalisation rates (Ersbøll/ Gravesen 20IO):

(C) Liberal naturalisation conditions lead to higher naturalisation rates, because less demanding or fewer requirements lower the effort required for naturalisation and increase the proportion of eligible immigrants.

(CI) Civic integration requirements in particular lead to lower naturalisation rates, as these are demanding in terms of time and resources.

(C2) Economic requirements for naturalisation limit the proportion of immigrants eligible for naturalisation and thus lead to lower naturalisation rates.

(C3) Naturalisation fees increase the costs of naturalisation and thus lead to lower naturalisation rates, specifically in a policy context which allows an otherwise easy access to naturalisation.

When Joppke $(2007,39)$ claims that naturalisation became a "rule-based routine", he correctly implies that naturalisation used to (and still might) be a risky process with no clear outcome. Waiting a long time, completing courses or taking tests, and paying substantial fees without certainty of obtaining citizenship may dampen the attraction of naturalisation. Especially in southern European countries, low naturalisation rates may be less a consequence of demanding requirements than of procedural uncertainty (Christopoulos 2009; Waldrauch 2006). Generally speaking, discretion in naturalisation processes can also provide opportunities for inclusion, not only for exclusion, e.g. by selectively exempting some applicants from certain requirements in order to avoid hardship (Dornis 200I). However, the operationalisation of procedural security applied here focuses on aspects, where large discretionary capacities clearly indicate a potential for exclusion, not for inclusion. ${ }^{2}$ The countries covered in this study vary in terms of procedural security, and it is thus possible to test a hypothesis on procedural security:

(D) Higher procedural security leads to higher naturalisation rates, because the risk of investing time and resources for naturalisation is lower.

That the availability of dual citizenship matters for naturalisation is underlined by several studies and concerns both the policy of the country 'of origin' and of residence (Reichel 20II; Vink et al. 20I3). While country of origin differences are beyond the scope of this study, an effect of dual citizenship policies of the country of residence is expected as follows:

(E) A possibility to obtain dual citizenship leads to higher naturalisation rates, because it provides easier opportunities to maintain ties with the country of origin.

\section{Operationalisation, data and descriptive statistics}

This paper builds on multivariate regression analysis of macro-level data, with naturalisation rates as dependent variable and naturalisation policy, economic development, government composition and immigrant inflows as independent variables. The model includes nine countries (Austria, Belgium, Denmark, Finland, Germany, Ireland, the Netherlands, Sweden and the United Kingdom) for a period of 20 years (1995 to 20I4). As EU member states which experienced major immigrant inflows in recent decades, these countries are suitable for comparing naturalisation outcomes. Given that many studies highlight substantial differences in citizenship policies in these countries, they constitute an adequate sample for investigating the effect of policies on naturalisation (Huddleston et al. 2OII; Koopmans et al. 2012). An inclusion of other EU countries in the sample is limited by data constraints, in particular for the early years of the analysed period. Immigration and naturalisation

2 The indicator on procedural security covers (a) whether there is a legal time frame within which applications for naturalisation need to be processed; (b) whether there is an entitlement to naturalisation (if all criteria are met), or an application can be rejected nonetheless; (c) whether applications can be rejected due to fraud or a possible threat to public security; (d) whether there are legal remedies against negative decisions. 
data for southern EU member states are not available, and citizenship policies often remain fairly vague so far.

Naturalisation rates are derived from EUROSTAT, taking the ratio of naturalisations and the resident foreign population per country/year. Given the purpose of assessing effects of naturalisation policies, these naturalisation rates do not include ius soli acquisitions and thus constitute what Janoski (2OI3) refers to as narrow naturalisation rates. In the sample of nine EU countries for the period 1995 to 2014, naturalisation rates vary greatly, both across and within countries, ranging from the Netherlands in 1996, where II.4\% of all foreign residents took up Dutch citizenship, to Denmark in 2013 , where just under $0.5 \%$ of all foreign residents did so. Overall, the mean naturalisation rate is $3.7 \%$ of all foreign residents naturalising per year. The variable is distributed fairly normally around the mean, with the notable exception of some particularly high naturalisation rates in the Netherlands in the I990s and in Sweden in $2007 / 08$.

Figure 1: Naturalisation rates in nine EU countries, 1995-20I4

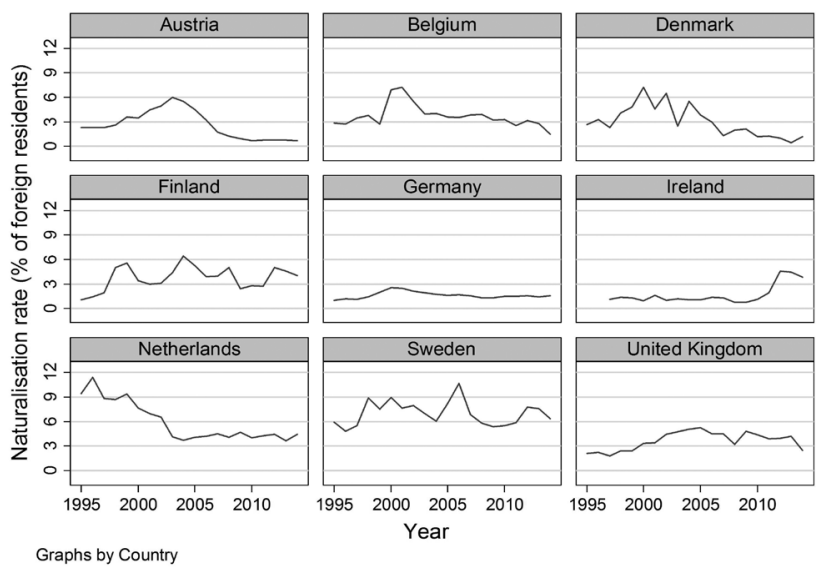

\section{Measuring naturalisation policies}

The policy variables for this analysis are mostly constructed in line with the Access to Nationality dimension of the Migrant Integration Policy Index (MIPEX). As recently proposed by Ruedin (2OI5), MIPEX data were disaggregated and recomposed in line with the theoretical approach described above. The MIPEX indicators were recomposed into five main policy dimensions, ranging from o to IOo, with the value of Ioo indicating maximum inclusion. ${ }^{3}$

3 MIPEX indicators used to construct the policy dimensions described below: ius soli: IO2-IO3; residence requirements: 98-IOO, IOIa; naturalisation conditions: I04a-c, I05a-c, I06-I09; procedural security: IIO-II3; dual citizenship: II5a-b. By taking the mean of the included indicators, which each include three coding options $(\mathrm{o}=$ exclusive,
Ius soli regulations describe whether second and third generation immigrants acquire citizenship at birth (two indicators). They range from an entire absence of ius soli, such as in Austria, to an automatic ius soli for the second and third generation, such as in Ireland. Most countries fall somewhere in between, where persons born in the country may acquire citizenship via declaration or simple application.

Residence requirements refer to the length of the standard residence requirement, whether it is necessary to have a permanent residence title, whether periods of absence are permissible and whether there are preferential conditions for spouses of citizens (four indicators). The most exclusive residence requirements are found in Austria and Denmark, where immigrants need to be resident for up to ten years (ordinary naturalisation in Austria), a certain period thereof must be based on a permanent residence permit and periods of absence are handled in an exclusive way. The most inclusive regulations on residence are again found in Ireland.

Naturalisation conditions cover all main naturalisation requirements other than residence: language skills, citizenship testing, economic resources, absence of a criminal record, or good character requirements; in line with the framework of MIPEX, naturalisation fees are also taken as conditions for acquisition (ten indicators). Within the dimension of naturalisation conditions, three requirements receive further attention: First, a separate variable of civic integration requirements includes six indicators of MIPEX on language and citizenship testing. These requirements have at times been particularly strong in Denmark, with required Danish language skill level of B2 and a citizenship test with low pass rates (Ersbøll/Gravesen 20I0). In contrast, such requirements have been absent in several countries, e.g. in Belgium from 2000 to 2012 . Second, a separate variable covers economic requirements for naturalisation and distinguishes between (a) applicants who must only provide evidence of economic means, without an explicit threshold, (b) explicit income, employment or welfare benefit requirements which include an exemption on social grounds, (c) such requirements without social exemption and a short reference period, and (d) such requirements with a reference period of more than one year (Stadlmair 20I4). Economic resource requirements were most strongly developed in Austria and Denmark from 2006 to 20I3, but other countries, such as Germany, Finland, or Ireland, also impose weaker forms of economic requirements. Third, naturalisation fees are covered as a separatevari-

$50=$ medium, $\mathrm{IOO}=$ inclusive $)$, each policy dimension has a theoretical range from o (exclusive) to Ioo (inclusive). Depending on the number of indicators covered, the number of theoretically possible scores varies for the different policy dimensions. Although some variables were regrouped with this approach, the main strategy of index construction is the same as in the original MIPEX structure (ibid.). 
Table 1: Descriptive statistics of dependent and independent variables

\begin{tabular}{|c|c|c|c|c|c|c|c|}
\hline \multirow[t]{2}{*}{ Variable } & \multirow[t]{2}{*}{ Min. } & \multirow[t]{2}{*}{ Max. } & \multirow[t]{2}{*}{ Mean } & \multicolumn{3}{|c|}{ Standard deviation } & \multirow[t]{2}{*}{$\mathrm{n}^{\mathrm{a}}$} \\
\hline & & & & Overall & Between & Within & \\
\hline Naturalisation rate & 0.5 & 11.4 & 3.7 & 2.3 & 1.8 & 1.5 & 178 \\
\hline Ius soli & 0 & 100 & 58.6 & 35.2 & 32.8 & 16.7 & 180 \\
\hline Residence requirement & 38 & 100 & 68.4 & 18.5 & 17.7 & 7.8 & 180 \\
\hline Naturalisation conditions & 19.5 & 83.3 & 52.3 & 16.9 & 14.5 & 9.9 & 180 \\
\hline Civic integration & 10 & 100 & 71.6 & 24.0 & 19.1 & 15.7 & 180 \\
\hline Economic requirements & 0 & 100 & 70.8 & 33.8 & 29.2 & 19.4 & 180 \\
\hline Naturalisation fees & 0 & 1123 & 433.3 & 324.6 & 310.2 & 137.4 & 173 \\
\hline Procedural security & 0 & 87.5 & 27.4 & 21.9 & 19.6 & 11.6 & 180 \\
\hline Dual citizenship & 50 & 100 & 84.7 & 16.8 & 12.2 & 12.2 & 180 \\
\hline Lagged immigrant inflow rates & 1.3 & 27.5 & 6.0 & 3.6 & 2.7 & 2.6 & 176 \\
\hline Share of EU citizens in \% of inflows & 0.03 & 0.84 & 0.37 & 0.19 & 0.16 & 0.12 & 178 \\
\hline Government composition & 1 & 5 & 2.7 & 1.4 & 0.6 & 1.2 & 180 \\
\hline GDP per capita & 18100 & 33300 & 24980 & 3036 & 2412 & 1991 & 177 \\
\hline
\end{tabular}

Notes: a: Number of observations (country-year combinations)

able, based on formal naturalisation fees controlled for inflation and purchasing power inequalities. ${ }^{4}$ Acquiring citizenship via naturalisation is fairly expensive in Ireland (a fee of iı $25 €$ for non-privileged applicants), Austria, the United Kingdom and the Netherlands. Belgium is the only country in this sample where naturalisation was free (from 2000 to 2012 ).

Procedural security describes discretion and transparency in the naturalisation process and the availability of judicial review (four indicators). The most uncertain naturalisation procedures are found in Ireland and the United Kingdom, where decisions are made highly discretionary, do not need to be made within a certain timeframe and include only limited possibilities for judicial review. The most transparent or secure procedures can be found in the Netherlands and in Belgium from 2013.

Dual citizenship covers the availability of dual citizenship in cases of naturalisation and - if not generally permitted - of categories of applicants exempt from a requirement to renounce the former citizenship (two indicators). Just as the other variables, the indicator for dual citizenship theoretically ranges from o (no possibility for dual citizenship in naturalisation procedures) to Ioo (dual citizenship always possible); Empirically, it ranges only from 50 to IOO, as there are no countries

4 In order to avoid a bias of differences in purchasing power over time, actual fees were controlled for annual average inflation rates within the EU-I5; to avoid bias due to differences in purchasing power across countries, inflation-controlled fees were then multiplied with purchasing power parities (http://ec.europa.eu/eurostat/web/ purchasing-power-parities/). covered which do not offer any exemptions from requirements to renounce the former citizenship. In order to account for this limited empirical variation, the indicator is recoded as a dummy variable, distinguishing only between an unrestricted possibility of dual citizenship (89 observations) and the presence of any restrictions on dual citizenship (9I observations).

For the period of 2007 to 2014, the data are available on the MIPEX website (http://www.mipex.eu/). For earlier years and for the variables on economic requirements and naturalisation fees, data were collected from secondary literature, in particular the NATAC and EUDO reports (http://eudo-citizenship.eu/), and from policy documents. ${ }^{5}$

Controls: GDP per capita, government composition, TCN and EU inflows

The control variables include a basic measure for Gross Domestic Product per capita, which is recommended by Janoski (2OIO) as a suitable and influential measure for the economic context shaping naturalisation rates. To account for changes of GDP values due to inflation, a specification as chain-linked volumes is offered by EUROSTAT, which eliminates inflation effects (http://ec.europa. eu/eurostat/en/web/products-datasets/-/TEINAoII).

5 I would like to thank Hilkka Becker, Sampo Brander, Dimitris Christopoulos, Betty de Hart, Eva Ersbøll, Anuscheh Farahat, Alberto Matrtín-Pérez, Patrick Wautelet, and Helena Wray from the EUDO Citizenship Observatory for contributing their country expertise to the data of this study. 
The variable on government composition is taken from the Comparative Political Data (CPDS) set of Armingeon et al. (2015), which reflects the share of left-wing government members in five categories (ranging from I to 5): The first category includes governments without any members affiliated to left parties, the last category includes governments composed only of left party members, the middle categories falling in-between. As CPDS data are only available until 2013, the values for the year 2014 were added by the author's own research.

Immigrant inflow rates are calculated using OECD data on the total population of a country/year divided by inflows of foreign citizens (inflow rate=population/ inflows* ${ }^{*}$ OOO). As immigrant inflows cannot be expected to lead to an immediate increase of naturalisation rates, they are lagged by approximate residence requirements. ${ }^{6}$ To account for variation within immigrant inflows, the proportion of EU citizens among immigrant inflows is included as separate variable. As data on immigrant inflows dating back to the I980s are scarce, the coverage of this analysis is limited to nine countries and some missing observations were interpolated. In Table I, immigrant inflows are displayed including lags and as the ratio of immigrant inflows per Iooo inhabitants of a country/year. Typically, this ratio ranges from 2.4 to 9.6 (mean of 6.0, standard deviation of 3.6), however, there are some observations of much higher values to a maximum of 27.5. These observations stem from Ireland in the late 200os, which experienced a strong inflow from citizens of Eastern European countries, which also led to an increase in naturalisations (see Figure I). The share of EU citizens among foreign inflows ranges from $3 \%$ (Finland in the 1990s) to $84 \%$ (Ireland in late 2000s).

\section{Model specifications}

With the exception of dual citizenship, all variables are interval-scaled and show considerable variation both within and between countries, suitable for a times-series cross-section analysis on the effect of policies on naturalisation outcomes. For this purpose, a standard OLS regression is insufficient and may lead to biased and overconfident results as it does not control for potential time- and panel-specific errors. The most common and appropriate response to these problems is to use a model with panel-corrected standard errors to account for differences across countries and a lagged dependent variable to account for differences over time (Beck/Katz

6 For Austria and Germany, inflow rates were lagged by Io years, for Denmark by 8 years, for all remaining countries inflow rates were lagged by 5 years. Lags for residence requirements cannot be calculated exactly, as requirements differ for various categories of applicant and underwent some amendments during the period of analysis, so this approach can only be an approximation. Using shorter or longer lags does not substantially alter the results in terms of model fit and statistical effects of the variables of interest.
1995; Wenzelburger et al. 2014, II9-160). In Stata, this specification is implemented in the xtpcse command, which is used as the main approach for this paper (labelled PCSE-LDV model henceforth).

Plümper and Tröger (2009, 265-267) argue that the lagged dependent variable may have smaller standard errors than the variables of interest, which may lead to underestimating their long-term effects. They propose a different model (Prais-Winsten transformation), which accounts for this problem and may thus show more substantial effects of the independent variables. This approach is applied as robustness check for the findings of the PSCE-LDV model.

Often time-series cross-section analyses include lags for independent variables, as their effect might theoretically be not immediate, but take some time to unfold (Janoski 20Io; Wenzelburger et al. 20I4). For an analysis of naturalisation rates, lagging the independent variables may not be appropriate, as there are many cases in which policy changes have an immediate effect on naturalisation outcomes. ${ }^{7}$

\section{Empirical results}

In a model containing only the lagged dependent variable and the policy dimensions outlined above, the only significant policy dimension is that of naturalisation conditions (model I). More inclusive conditions for naturalisation can account for higher naturalisation rates - and vice versa. Figure $2 \mathrm{a}$ displays this result in a marginal effects plot: For instance, a decrease from the value of 6 I to the value of 28 - which reflects the policy changes in Denmark in 2006, where economic requirements and citizenship tests were introduced - corresponds to an estimated change in naturalisation rates of I (de facto Danish naturalisation rates decreased from 3.8 in 2005 to 2.9 in 2006).

Once GDP per capita, government composition, and immigrant inflows are included as controls (model 2), dual citizenship and ius soli also have a significant effect on naturalisation rates: As expected, ius soli has a negative effect, with a change from no ius soli (value o) to full ius soli (value Ioo) leading to an estimated change in naturalisation rates of 0.87 . With a value of 0.74 , the estimated positive effect of permitting unrestricted dual citizenship (as opposed to exceptional dual citizenship) is slightly weaker. Residence requirements remain insignificant in model 2. However, naturalisation conditions again have the greatest predicted effect on naturalisation rates, where a theoretical shift from full exclusion

7 For instance, naturalisations dropped quite immediately after restrictive policy amendments in Austria and Denmark in the mid20oos, or increased strongly after a liberalising reform in Belgium in 2000 (Ersbøll 2006; Foblets/Loones 2006; Stern/Valchars 20I3). 
Table 2: PCSE-LDV regression results

\begin{tabular}{|c|c|c|c|c|}
\hline Model & $(1)$ & $(2)$ & (3) & $(4)$ \\
\hline \multicolumn{5}{|l|}{ Policy dimensions } \\
\hline \multirow[t]{2}{*}{ Ius soli } & -0.00472 & $-0.00865^{*}$ & $-0.0109^{* * *}$ & $-0.00556^{*}$ \\
\hline & $(0.00327)$ & $(0.00337)$ & $(0.00268)$ & $(0.00282)$ \\
\hline \multirow[t]{2}{*}{ Residence requirements } & 0.00196 & 0.00944 & & \\
\hline & $(0.00556)$ & $(0.00649)$ & & \\
\hline \multirow[t]{2}{*}{ Naturalisation conditions } & $0.0305^{* * *}$ & $0.0291^{* * *}$ & & \\
\hline & $(0.00691)$ & $(0.00692)$ & & \\
\hline \multirow[t]{2}{*}{ Procedural security } & 0.00617 & 0.00549 & & \\
\hline & $(0.00558)$ & $(0.00512)$ & & \\
\hline \multirow[t]{2}{*}{ Dual citizenship (dummy variable) } & 0.488 & $0.739 * *$ & & \\
\hline & $(0.296)$ & $(0.248)$ & & \\
\hline \multicolumn{5}{|l|}{ Naturalisation conditions } \\
\hline \multirow[t]{2}{*}{ Civic integration requirements } & & & 0.00515 & \\
\hline & & & $(0.00387)$ & \\
\hline \multirow[t]{2}{*}{ Economic requirements } & & & $0.0155^{* * *}$ & \\
\hline & & & $(0.00341)$ & \\
\hline \multirow[t]{2}{*}{ Naturalisation fees } & & & -0.0000691 & -0.00147 \\
\hline & & & $(0.000222)$ & $(0.002)$ \\
\hline \multirow{2}{*}{$\begin{array}{l}\text { Policy index (excluding civ. int., ec. } \\
\text { req., nat. fees) }\end{array}$} & & & $0.0287^{* * *}$ & \\
\hline & & & $(0.00732)$ & \\
\hline \multirow[t]{2}{*}{ Policy index (excluding nat. fees) } & & & & 0.0311 \\
\hline & & & & $(0.0194)$ \\
\hline \multirow{2}{*}{$\begin{array}{l}\text { Interaction term of fees and policy } \\
\text { index }\end{array}$} & & & & 0.0000235 \\
\hline & & & & $(0.0000338)$ \\
\hline \multicolumn{5}{|l|}{ Control variables } \\
\hline \multirow[t]{2}{*}{ Lagged immigrant inflows } & & $0.0523^{*}$ & 0.0316 & 0.0264 \\
\hline & & $(0.0208$ & $(0.0236)$ & $(0.0248)$ \\
\hline \multirow[t]{2}{*}{ EU-share of inflows } & & $-1.129^{*}$ & -0.707 & -0.501 \\
\hline & & $(0.547)$ & $(0.569$ & $(0.515)$ \\
\hline \multirow[t]{2}{*}{ Government composition } & & $0.133^{*}$ & $0.164^{\star *}$ & $0.149^{*}$ \\
\hline & & $(0.0672)$ & $(0.0591)$ & $(0.0644)$ \\
\hline \multirow[t]{2}{*}{ GDP per capita } & & -0.00000251 & -0.000033 & -0.0000335 \\
\hline & & $(0.0000345)$ & $(0.0000324)$ & $(0.0000306)$ \\
\hline \multirow[t]{2}{*}{ Lagged naturalisation rate (dependent variable) } & $0.684^{* * *}$ & $0.665^{* * *}$ & $0.648^{* * *}$ & $0.760^{\star \star *}$ \\
\hline & $(0.0573)$ & $(0.0528)$ & $(0.053)$ & $(0.0492)$ \\
\hline \multirow[t]{2}{*}{ Intercept } & -0.693 & -1.13 & -0.586 & -0.139 \\
\hline & $(0.401)$ & $(1.027)$ & $(0.946)$ & $(1.347)$ \\
\hline Observations & 176 & 175 & 168 & 168 \\
\hline Adjusted R-squared & 0.7875 & 0.7996 & 0.7958 & 0.7751 \\
\hline
\end{tabular}


Figure 2a/b: marginal effects of naturalisation conditions and economic requirements

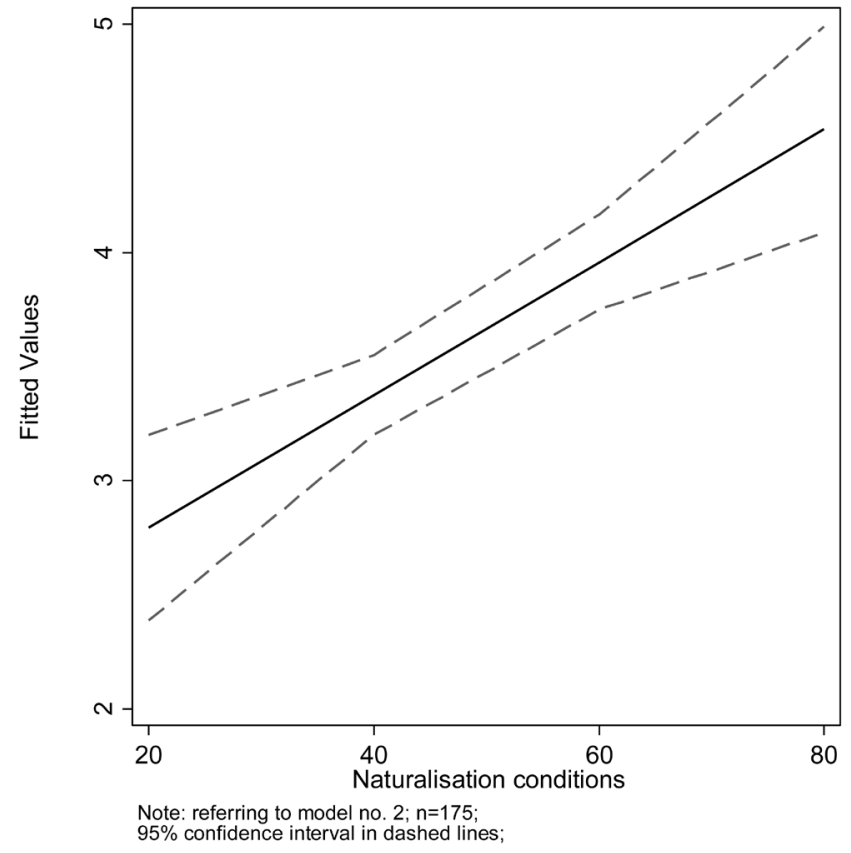

to full inclusion would lead to an estimated change of naturalisation rates of 2.9. Based on these findings, it may however be interesting which conditions matter: Are differences in naturalisation related to trends of civic integration requirements, do economic requirements matter, or are the often substantial fees possible reasons for this effect?

Model 3 investigates different components of naturalisation conditions, namely civic integration requirements (language and citizenship tests), economic requirements for naturalisation and naturalisation fees. The remaining indicators on naturalisation policy are summarised to one index (residence requirements, good conduct, good character, procedural security, and dual citizenship). It shows that economic requirements drive the effect of naturalisation conditions on naturalisation rates, while civic integration requirements and naturalisation fees are not significant. The marginal effects are displayed in Figure $2 b$, which shows that the difference between the most elaborate economic requirements (value o) and the absence of such requirements (value IOo) is about I.I6 on estimated naturalisation rates.

Fees are not significant in model 3. As outlined theoretically, fees might have a conditional effect depending on general policy inclusiveness. Following this argument, we may expect an interaction effect between fees and an overall index of naturalisation policy, where fees should be significant only if the index has high values. Model 4 includes this interaction effect and shows that the (insignificant) effect of fees does not vary by different levels of policy inclusiveness.

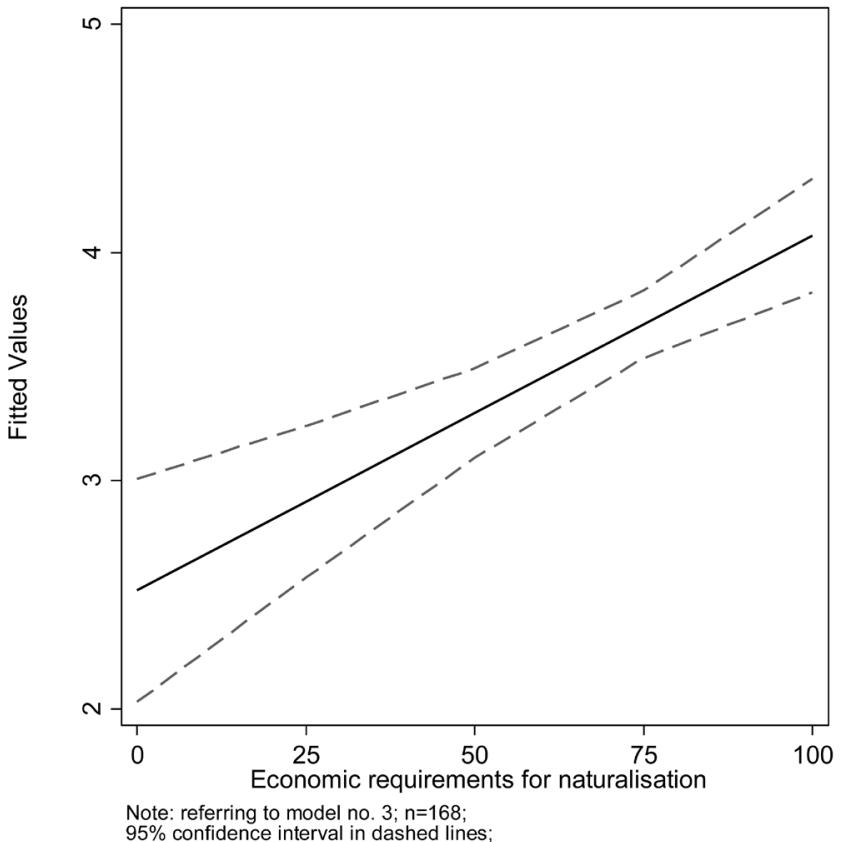

\section{Robustness checks}

The models discussed above already include a lagged dependent variable to account for serial autocorrelation, as otherwise the errors would be serially correlated. ${ }^{8}$ To check for problems due to a heterogeneity of units, a fixed-effects regression with the same independent variables as in model 3 is applied and confirms that heterogeneity across units is already sufficiently covered by the independent variables in the model (insignificant Fvalue of fixed-effects model).

Tests for potential heteroscedasticity are also limited, as the model already includes a measure for panel-corrected standard errors. Checking the raw residuals of model 3, Figure 3a shows their even distribution over time; Figure $3 \mathrm{~b}$ shows that strong outliers typically are observations with very high naturalisation rates. ${ }^{9}$ In other words, the model can explain low and average naturalisation rates fairly well, but exceptional circumstances with more naturalisations than usual call for further attention:

Dutch naturalisation rates in the mid-I990s were unusually high, according to van Oers et al. (2006, 4I7) a consequence of a phase in which dual citizenship was

8 Including the same variables as in the models of Table 2 without a lagged DV, a Woolridge test for autocorrelation confirms the expected serial correlation of errors, which is eliminated by including a lagged DV.

9 Running a separate model excluding observations with unusually high naturalisation rates $(>8, \mathrm{n}=\mathrm{I} 6 \mathrm{I})$ confirms the findings of the fuller model. Observations with high naturalisation rates thus do not substantially influence the empirical results. 
Figure 3a/b: Raw residuals by year and by levels of naturalisation rates

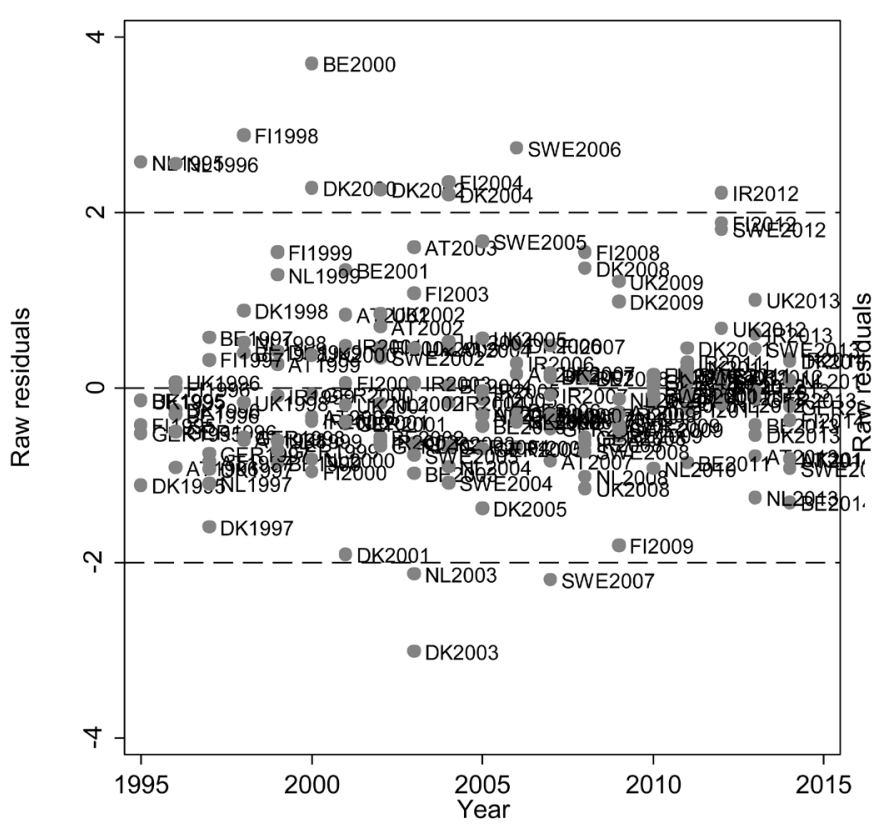

Note: Raw residuals of model no. 3

available unconditionally. In Belgium a sudden increase of naturalisations in $2000 \mathrm{can}$ also be attributed to policy reform, which is unfortunately not adequately covered in the MIPEX coding scheme (Foblets/Loones 2006). The outliers for Sweden (2006/2007) are more puzzling. One possible explanation might be backlogs in the processing of naturalisation applications, which were remedied by institutional reforms and a possibility to appeal against negative decisions in 2006 (Lokrantz Bernitz/Bernitz 2006, 537-544). Denmark in 2003 is the only observation in which naturalisations were severely overestimated. This large residual likely stems from the mid-year introduction of formal Danish language assessments in 2002, which is estimated to have had an immediate effect on the 2002 rates, but according to Ersbøll (2006, I33) is only visible in the 2003 naturalisation rates, as there were many naturalisations granted in the first half of the year 2002. Overall, most outliers may be attributed to policy changes and their timing and underline the difficulty of adequately measuring policy development. ${ }^{\text {Io }}$

As mentioned above, the model specification, including a lagged dependent variable and panel-cor-

IO Outlier cases due to a delayed effect of policy changes may be addressed by lagging the relevant independent variables (Janoski 20IO). Lagging all variables by one year, I find the same effects as in the unlagged approach (Table 2), but a slightly worse model fit and larger residuals. This approach thus creates more problems than it actually solves. If the outlying observations discussed above are excluded from the model altogether, the same variables of interest are significant as in models including all observations, except for dual citizenship and ius soli, which then have no significant effect on naturalisation rates. rected standard errors, faces criticism for being overly restrictive: In particular the lagged DV may account for so much variation that other factors underlying naturalisation outcomes may be falsely considered insignificant because they cannot fully explain year-by-year differences (Plümper/Troeger 2009). The alternative proposed by Plümper and Tröger is a Prais-Winsten specification, which does not include a lagged DV. Comparing the models described in Table 2 with a Prais-Winsten model (see ANNEX), including the same variables except from the lagged dependent variable, confirm the findings of the PCSE-LDV model, but - as expected - reveals stronger effects of the variables of interest. Procedural security and civic integration requirements also show a significant effect on naturalisation rates in the Prais-Winsten model. Fees for naturalisation remain insignificant, with a more pronounced interaction effect but large confidence intervals for fees higher than approximately $600 €$.

\section{Discussion}

The empirical results provide robust evidence that citizenship policies have an independent and substantial effect on naturalisation rates in full models including relevant control variables, confirming the findings of Janoski (2OIO) and Reichel (2OII). Moving beyond a general effect of policies on naturalisation outcomes, they show that some dimensions of naturalisation policies are more relevant for explaining naturalisation rates 
than others. It remains however to contextualise these findings and its constraints in terms of methods and data used. As the analysis draws on aggregate data, taking country/years as units of analysis instead of individual persons, the effects of policies on individual decisions concerning naturalisation fall out of sight. Therefore, the findings may deepen an understanding of which aspects of policies shape overall naturalisation outcomes, but cannot explain naturalisation as such, since many important factors cannot accounted for in this model.

Confirming hypothesis (A), the availability of ius soli indeed corresponds to lower naturalisation rates, although such an effect is only significant in a full model with control variables. As ius soli constitutes an additional possibility to obtain citizenship and does not regulate naturalisation per se, this evidence is not surprising (Reichel 2012). Even so, it refutes a 'deflation effect', where the absence of ius soli leads to higher proportions of foreign residents, which in turn would deflate naturalisation rates (Vink 2010). Turning to naturalisation policy dimensions in a narrow sense, residence requirements cannot independently explain levels of naturalisation rates. Assuming that potential naturalisations are delayed depending on the length of legally required residence, there is no evidence that naturalisation rates are lower if potential applicants have to wait longer to naturalise. This is not in line with what one might expect based on research using survey or register data, which shows that the propensity to naturalise decreases with the length of individual residence (Peters et al. 2016). Also when applying shorter or longer lags for immigrant inflows, there is no statistically significant effect of residence requirements on naturalisation rates. Consequently, hypothesis (B) is rejected. The most solid effect of policies on naturalisation is the effect of naturalisation conditions: More demanding requirements correspond to fewer naturalisations, leading to a confirmation of hypothesis (C). Within the set of possible conditions for naturalisation, civic integration requirements only have an effect on naturalisation in the Prais-Winsten model but not in the more restrictive PCSE-LDV model. This evidence supports arguments which question the purpose of such requirements, rendering them primarily symbolic politics (Mourão Permoser 2012). However, there is no solid evidence for confirming hypothesis (CI).

Of the naturalisation conditions, the findings support the view that in particular economic requirements supress naturalisation. If access to citizenship is tied to some form of economic independence - be it not receiving welfare benefits, having stable employment, or meeting an income threshold - there are fewer naturalisations compared to countries in which such requirements are not in place or more lenient. This finding is of particular relevance, as an increasing number of countries make access to citizenship conditional upon economic resources (van Houdt et al. 20II; Stadlmair 20I4). One country with particularly complex economic requirements for naturalisation is Austria, for which Joachim Stern (2012) estimated for the year 2010 that for a single person a net income of under rooo€ per month was very likely insufficient for naturalisation. Reichel and Perchinig (2015) confirm this estimate with census data, showing that income is an important individual-level indicator for naturalisation in Austria, with only few low-income immigrants actually obtaining Austrian citizenship. Confirming hypothesis $\left(\mathrm{C}_{2}\right)$, this paper shows that a focus on economic resources can be associated with fewer naturalisations on an aggregate level.

Naturalisation fees do not seem to play a role for naturalisation in a comparison of cross-national differences in naturalisation rates. There is neither an independent nor a clear conditional effect, leading to the rejection of hypothesis $\left(\mathrm{C}_{3}\right)$. The very weak interaction of naturalisation fees and policy inclusiveness implies that naturalisation fees might have a stronger effect in a context in which naturalisation is otherwise easily accessible. However, given that both naturalisation fees and naturalisation policy inclusiveness are not correlated and vary quite substantially in the sample of countries studied as well as within countries over the period of analysis, it is rather surprising that this effect is not significant. Interpreting this finding it seems that, unlike public services, citizenship acquisition cannot be effectively regulated via fees (Grohs et al. 20I3).

Differences in procedural security have no clear effect on naturalisation rates when using the PCSE-LDV approach, but they do when using Prais-Winsten approach. Therefore hypothesis (D) cannot be confirmed with solid evidence, calling for further research on discretion in naturalisation processes. An availability of dual citizenship corresponds to higher naturalisation rates, at least when including all control variables, confirming hypothesis (E) and the findings of Reichel (2OII) with a larger data set.

In line with the findings of Janoski (2010), immigrant inflow rates have no clear and direct effect on naturalisation rates, even when using appropriate lags based on the duration of residence requirements and controlling for the share of EU-citizens among inflows. In the PCSE-LDV model, the variable on government composition confirms the expected effect of left-wing party power on naturalisation rates (ibid.). Economic development does not seem to have an impact on naturalisation rates, as the variable on GDP per capita is always insignificant. However, this finding may be attributed to the relatively homogeneous economic development of the countries covered in the sample. 


\section{Conclusion}

Given that European societies continue to be shaped by mobility across borders, citizenship may remain a tool for drawing legal and discursive boundaries and stratifying access to public goods (Ataç/Rosenberger 2013). Therefore strategies of inclusion and exclusion may involve criteria for conferring citizenship. The results presented in this paper support the view that ius soli and naturalisation policies are effectively shaping naturalisation outcomes on an aggregate level, both in cross-national comparison and over time: In particular, an availability of birthplace citizenship tends to decrease naturalisation rates, as fewer persons then need to undergo a naturalisation procedure to obtain the citizenship of their country of residence. As expected, unrestricted dual citizenship corresponds to higher naturalisation rates. Of the naturalisation conditions, civic integration requirements and naturalisation fees do not have clear effects on naturalisation rates, but economic requirements clearly do. Such requirements are increasingly common for citizenship in Western European countries, but also concern other rights, such as family reunion (van Houdt et al. 20II). Their substantial effect on naturalisation outcomes points to an economic stratification of access to fundamental rights. Such intersections of economic and legal inequality clearly violate a Marshallian (I950) concept of equal citizenship and may provide the subject for further research on the intersections of class and citizenship (Reichel/Perchinig 2015).

Although these findings may be of interest for an academic and public discussion of the pros and cons of different approaches towards naturalisation, there are two core constraints to be kept in mind: First, the findings only include the level of naturalisations as subject of interest and not the competences, attitudes, social or economic situation of those who do (not) naturalise. In other words, if naturalisation is about selecting some persons to include in the demos while excluding others (Anderson/Hughes 2015; Joppke 2007), the mere level of naturalisations is only one side of the coin, the expected characteristics of those included and excluded is another topic. Second, unlike other recent studies (Peters et al. 2016; Reichel/Perchinig 2015) this analysis is not based on surveys but on national year-to-year aggregate naturalisation data. It cannot draw conclusions on individual behaviour or on the way in which policies affect immigrants with specific characteristics - be it age, education, country of origin, etc. This remains a perspective for future research.

\section{Literature}

Anderson, Bridget/Vanessa Hughes (eds.) (2015). Citizenship and its Others, London.

Armingeon, Klaus/Christian Isler/Laura Knöpfel/David Weisstanner/et al. (2015). Comparative Political Data Set 1960-2013, Bern: Institute of Political Science: University of Bern. Internet: http://www.cpds-data. $\mathrm{org} /$ (accessed 30.6.2016).

Ataç, Ilker/Sieglinde Rosenberger (eds.) (2OI3). Politik der Inklusion und Exklusion, Vienna.

Bauböck, Rainer (20I0). Changing the boundaries of citizenship: the inclusion of immigrants in democratic polities, in: Marco Martiniello/Jan Rath (eds.): Selected Studies in International Migration and Immigrant Incorporation, Amsterdam, 276-313.

Beck, Nathaniel/Jonathan N. Katz (1995). What to Do (and Not to Do) with Time-Series Cross-Section Data, in: American Political Science Review, Vol. 89(3), 634647.

Bevelander, Pieter/Don DeVoretz (eds.) (2008). The Economics of Citizenship, Malmö.

Brubaker, Rogers (1992). Citizenship and Nationhood in France and Germany, Cambridge.

Christopoulos, Dimitris (2009). Defining the Changing Boundaries of Greek Nationality, in: Dimitris Tziovas (ed.): Greek Diaspora and Migration since 1700. Society, Politics and Culture, Farnham, III-I24.

Dornis, Christian (200I). Einbürgerung in Deutschland: Die Verwaltungspraxis in verschiedenen Regionen im Vergleich, in: Lale Akgün/Dietrich Thränhardt (eds.): Integrationspolitik in föderalistischen Systemen, Münster, 63-90.

Dronkers, Jaap/Maarten Vink (2012). Explaining access to citizenship in Europe: How citizenship policies affect naturalization rates, in: European Union Politics, Vol. I3(3), 390-4I2.

Ersbøll, Eva (2006). Denmark, in: Rainer Bauböck/Eva Ersbøll/Kees Groenendijk/Harald Waldrauch (eds.): Acquisition and Loss of Nationality. Country Analyses, Amsterdam, IO5-I48.

Ersbøll, Eva/Laura Katrine Gravesen (20I0). Country Report Denmark, Nijmegen: Radboud University Nijmegen. Internet: http://www.humanrights.dk/focus+areas/ research/results/intec+report (accessed 4.I2.2OI3).

Foblets, Marie-Claire/Sander Loones (2006). Belgium, in: Rainer Bauböck/Eva Ersbøll/Kees Groenendijk/Harald Waldrauch (eds.): Acquisition and Loss of Nationality. Country Analyses, Amsterdam, 63-IO4.

Goodman, Sara Wallace (20I4). Immigration and Membership Politics in Western Europe, Cambridge.

Grohs, Stephan/Christoph Knill/Jale Tosun (2013). Der Gebührenstaat. Theoretische Überlegungen und empirische Befunde, in: Der Moderne Staat, Vol. 6(I), I3II52. 
de Groot, Gerard-René (1989). Staatsangehörigkeitsrecht im Wandel, Cologne.

Hagedorn, Heike (200I). Wer darf Mitglied werden? Einbürgerung in Deutschland und Frankreich im Vergleich, Opladen.

van Houdt, Friso/Semin Suvarierol/Willem Schinkel (2OII). Neoliberal communitarian citizenship: Current trends towards 'earned citizenship' in the United Kingdom, France and the Netherlands, in: International Sociology, Vol. 26(3), 408-432.

Howard, Marc Morjé (2009). The Politics of Citizenship in Europe, Cambridge.

Huddleston, Thomas/Jan Niessen/Eadaoin Ni Chaoimh/ Emilie White (20II). Migrant Integration Policy Index III, Brussels: British Council and Migration Policy Group. Internet: http://www.mipex.eu/download (accessed 13.6.2013).

Janoski, Thomas (2013). The complexities of measuring naturalization rates in advanced industrialized countries, in: Comparative European Politics, Vol. II(5), 649-670.

Janoski, Thomas (2010). The Ironies of Citizenship. Naturalization and Integration in Industrialized Countries, Cambridge.

Joppke, Christian (2003). Citizenship between De- and Re-Ethnicization, in: European Journal of Sociology, Vol. 44(3), 429-458.

Joppke, Christian (2007). Transformation of Citizenship: Status, Rights, Identity, in: Citizenship Studies, Vol. II(I), 37-48.

Koopmans, Ruud/Ines Michalowski/Stine Waibel (2012). Citizenship rights for immigrants: national political processes and cross-national convergence in western Europe, 1980-2008, in: AJS; American Journal of Sociology, Vol. II7(4), I2O2-I245.

Koopmans, Ruud/Paul Statham/Marco Giugni/Florence Passy (2005). Contested Citizenship: Immigration and Cultural Diversity in Europe, Minneapolis.

Lokrantz Bernitz, Hedvig/Henrik Bernitz (2006). Sweden, in: Rainer Bauböck/Eva Ersbøll/Kees Groenendijk/ Harald Waldrauch (eds.): Acquisition and Loss of Nationality. Country Analyses, Amsterdam, 517-550.

Marshall, Thomas Humphrey (1950). Citizenship and Social Class: And Other Essays.

Mourão Permoser, Julia (2OI2). Civic Integration as Symbolic Politics: Insights from Austria, in: European Journal of Migration and Law, Vol. I4(2), I73-198.

OECD (2OII). Naturalisation: A Passport for the Better Integration of Immigrants?, Paris: OECD Publishing. van Oers, Ricky/Betty de Hart/Kees Groenendijk (2006). The Netherlands, in: Rainer Bauböck/Eva Ersbøll/Kees Groenendijk/Harald Waldrauch (eds.): Acquisition and Loss of Nationality. Country Analyses, Amsterdam, 39I-434.
Peters, Floris/Maarten Vink/Hans Schmeets (2016). The ecology of immigrant naturalisation: a life course approach in the context of institutional conditions, in: Journal of Ethnic and Migration Studies, Vol. 42(3), 359-38I.

Plümper, Thomas/Vera E. Troeger (2009). Fortschritte in der Paneldatenanalyse: Alternativen zum de facto Beck-Katz-Standard, in: Susanne Pickel/Gert Pickel/ Hans-Joachim Lauth/Detlef Jahn (eds.): Methoden der vergleichenden Politik- und Sozialwissenschaft, Wiesbaden, 263-276.

Reichel, David (20II). Do legal regulations hinder naturalisation? Citizenship policies and naturalisation rates in Europe, Florence: EUDO Citizenship Observatory.

Reichel, David/Bernhard Perchinig (2015). Reflections on the value of citizenship - explaining naturalisation practices, in: Austrian Journal of Political Science, Vol. 44(I), 32-45.

Reichel, David (2012). Regulating Political Incorporation of Immigrants - Naturalisation Rates in Europe, ICMPD Working Paper, Vienna: International Centre for Migration Policy Development. Internet: http:// research.icmpd.org/fileadmin/Research-Website /Publications/working_papers/Reichel_Naturalisa tion_Rates_Europe_2OI2.pdf (accessed I9.12.2016).

Ruedin, Didier (2015). Increasing Validity by Recombining Existing Indices: MIPEX as a Measure of Citizenship Models, in: Social Science Quarterly, Vol. 96(2), 629-638.

Stadlmair, Jeremias (20I4). Ökonomische Einbürgerungsvoraussetzungen im europäischen Vergleich: Irland, Dänemark und Österreich, in: Karin Schnebel (ed.): Europäische Minderheiten. Im Dilemma zwischen Selbstbestimmung und Integration, Wiesbaden, 165-200.

Stern, Joachim (2012). Ius Pecuniae - Staatsbürgerschaft zwischen ausreichendem Lebensunterhalt, Mindestsicherung und Menschenwürde, in: Julia Dahlvik (ed.): Migration und Integration, Göttingen, 55-73.

Stern, Joachim/Gerd Valchars (2013). Austria, San Domenico di Fiesole: EUDO Citizenship Observatory. Internet: http://eudo-citizenship.eu/countryprofiles/? country=Austria (accessed 15.3.2015).

Vink, Maarten (2010). Naturalisation rates and rejection rates measure different phenomena, and have different problems, Florence: EUDO Citizenship Observatory, Internet: http://eudo-citizen ship.eu/commentaries/citizenship-forum/citizen ship-forum-cat/380-which-indicators-are-mostuseful-for-comparing-citizenship-policies? showall $=\&$ start $=2$ (accessed 13.7.2016).

Vink, Maarten/Tijana Prokic-Breuer/Jaap Dronkers (2013). Immigrant Naturalization in the Context of Institutional Diversity: Policy Matters, but to Whom?, in: International Migration, Vol. 5I(5), I-20. 
Waldrauch, Harald (2006). Statistics on acquisition and loss of nationality, in: Rainer Bauböck/Eva Ersbøll/ Kees Groenendijk, Kees/Harald Waldrauch (eds.): Acquisition and Loss of Nationality. Comparative Analyses, Amsterdam, 269-316.

Wenzelburger, Georg/Sebastian Jäckle/Pascal König (2014). Weiterführende statistische Methoden für Politikwissenschaftler. Eine anwendungsbezogene Einführung mit Stata, Oldenburg.

Yang, Philip Q. (1994). Explaining Immigrant Naturalization, in: The International Migration Review, Vol. 28(3), 449-477.

\section{Author}

Jeremias Stadlmair (1987) is a PhD student at the Department of Political Science of the University of Vienna and member of the research group IN:EX Politics of Inclusion and Exclusion. His research interests comprise citizenship and migration policies in Europe, political participation, and direct democracy. Recent publications include: "Die meritokratische Neugestaltung der österreichischen Integrationspolitik zwischen Rhetorik und Policy", in: Austrian Journal of Political Science (ÖZP), Vol. 45(I), 2016, 65-79 (together with Oliver Gruber and Astrid Mattes); "Petitionen und Parlamentarische Bürgerinitiativen: Zivilgesellschaft im Parlament?", in: TransForm - Journal für Zivilgesellschaftliche Innovation, Vol. I, 2016, 68-100 (together with Sieglinde Rosenberger). 
Appendix: Prais-Winsten regression results

\begin{tabular}{|c|c|c|c|c|}
\hline Model & $(1)$ & $(2)$ & (3) & $(4)$ \\
\hline \multicolumn{5}{|l|}{ Policy dimensions } \\
\hline \multirow[t]{2}{*}{ Ius soli } & $-0.0183^{*}$ & $-0.0190^{*}$ & $-0.0215^{\star *}$ & $-0.0240^{* *}$ \\
\hline & $(0.0072)$ & $(0.00743)$ & $(0.00715$ & $(0.00809)$ \\
\hline \multirow[t]{2}{*}{ Residence requirements } & 0.0224 & 0.0302 & & \\
\hline & $(0.0147)$ & $(0.0159)$ & & \\
\hline \multirow[t]{2}{*}{ Naturalisation conditions } & $0.0872^{\star * *}$ & $0.0840^{* * *}$ & & \\
\hline & $(0.0127)$ & $(0.0137)$ & & \\
\hline \multirow[t]{2}{*}{ Procedural security } & $0.0333^{* * *}$ & $0.0301^{* *}$ & & \\
\hline & $(0.00888)$ & $(0.00921)$ & & \\
\hline \multirow[t]{2}{*}{ Dual citizenship (dummy variable) } & $1.307^{\star *}$ & $1.405^{* *}$ & & \\
\hline & $(0.434)$ & $(0.442)$ & & \\
\hline \multicolumn{5}{|l|}{ Naturalisation conditions } \\
\hline \multirow[t]{2}{*}{ Civic integration requirements } & & & $0.0235^{* *}$ & \\
\hline & & & $(0.00809)$ & \\
\hline \multirow[t]{2}{*}{ Economic requirements } & & & $0.0261^{* * *}$ & \\
\hline & & & $(0.00619)$ & \\
\hline \multirow[t]{2}{*}{ Naturalisation fees } & & & -0.000181 & 0.00434 \\
\hline & & & $(0.00078)$ & $(0.00531)$ \\
\hline \multirow{2}{*}{$\begin{array}{l}\text { Policy index (excluding civ. int., ec. req., } \\
\text { nat. fees) }\end{array}$} & & & $0.103^{* * *}$ & \\
\hline & & & $(0.0213)$ & \\
\hline \multirow[t]{2}{*}{ Policy index (excluding nat. fees) } & & & & $0.203^{\star * \star}$ \\
\hline & & & & $(0.0446)$ \\
\hline \multirow{2}{*}{$\begin{array}{l}\text { Interaction term of fees and policy } \\
\text { index }\end{array}$} & & & & -0.0000898 \\
\hline & & & & $(0.0000927)$ \\
\hline \multicolumn{5}{|l|}{ Control variables } \\
\hline \multirow[t]{2}{*}{ Lagged immigrant inflows } & & 0.0698 & 0.0548 & 0.0422 \\
\hline & & $(0.0494)$ & $(0.0509)$ & $(0.0543)$ \\
\hline \multirow[t]{2}{*}{ EU-share of inflows } & & -1.411 & -2.001 & -1.232 \\
\hline & & $(1.641)$ & $(1.459)$ & $(1.707)$ \\
\hline \multirow[t]{2}{*}{ Government composition } & & 0.115 & 0.12 & 0.126 \\
\hline & & $(0.117)$ & $(0.116)$ & $(0.118)$ \\
\hline \multirow[t]{2}{*}{ GDP per capita } & & 0.0000516 & 0.0000201 & -0.0000151 \\
\hline & & $(0.0000857)$ & $(0.0000858)$ & $(0.000101)$ \\
\hline \multirow[t]{2}{*}{ Intercept } & $-3.036^{*}$ & -4.774 & -4.581 & -6.634 \\
\hline & $(1.258)$ & $(2.54)$ & $(2.51)$ & $(3.492)$ \\
\hline Observations & 178 & 176 & 169 & 169 \\
\hline Adjusted R-squared & 0.271 & 0.273 & 0.285 & 0.222 \\
\hline
\end{tabular}


